\title{
RECORD OF THE PEA-CRAB Calyptraeotheres garthi (FENUCCI, 1975) (BRACHYURA, PINNOTHERIDAE) IN TROPICAL ATLANTIC OCEAN
}

\section{Registro do caranguejo Calyptraeotheres garthi (Fenucci, 1975) (Brachyura, Pinnotheridae) no Oceano Atlântico tropical}

\author{
Felipe Bezerra Ribeiro1, Helena Matthews-Cascon², Luís Ernesto Arruda Bezerra3 \\ ${ }^{1}$ Programa de Pós-graduação em Biologia Animal, Departamento de Zoologia (Laboratório de Carcinologia), \\ Instituto de Biociências, Universidade Federal do Rio Grande do Sul. E-mail: fbribeiro.bio@gmail.com \\ ${ }^{2}$ Laboratório de Invertebrados Marinhos do Ceará (Limce), Departamento de Biologia, Centro de Ciências, \\ Universidade Federal do Ceará \\ ${ }^{3}$ Programa de Pós-Graduação em Ciências Marinhas Tropicais, Instituto de Ciências do Mar (Labomar), \\ Universidade Federal do Ceará
}

\begin{abstract}
This study reports the occurrence of the pea-crab Calyptraeotheres garthi (Fenucci, 1975) for the State of Ceará, Northeastern Brazil. The crab was found associated to the calyptraeid limpet Crepidula plana (Say, 1822) in a Voluta ebraea (Linnaeus, 1758) shell occupied by the hermit crab Petrochirus diogenes (Linnaeus, 1758). This record represents the northernmost occurrence for the species in the Atlantic Ocean and the second for Brazilian waters. This new record increases the distribution area of C. garthi in about 3520 $\mathrm{km}$. Taxonomic and biogeographic remarks, ecological notes and an updated distribution map are provided for this species.
\end{abstract}

Keywords: Pinnotherids, gastropods, tropical beach, symbiotic crustaceans.

\section{RESUMO}

Este estudo relata a ocorrência do caranguejo Calyptraeotheres garthi (Fenucci, 1975) no estado do Ceará, Nordeste do Brasil. O caranguejo foi encontrado associado ao molusco caliptraeídeo Crepidula plana (Say, 1822), em uma concha de Voluta ebraea (Linnaeus, 1758) ocupada pelo ermitão Petrochirus diogenes (Linnaeus, 1758). Essa ocorrência representa o registro mais ao norte para essa espécie no Oceano Atlântico e o segundo para as águas brasileiras. Essa nova ocorrência 
aumenta a área de distribuição de C. garthi em cerca de $3.520 \mathrm{~km}$. Observações taxonômicas e biogeográficas, notas ecológicas e um mapa de distribuição atualizado são fornecidos para essa espécie.

Palavras-chave: Pinoterídeos, gastrópodos, praia tropical, crustáceos simbiontes.

The pea-crabs belongs to the family Pinnotheridae De Haan, 1833 and are well known as commensals or parasites of marine invertebrates as bivalves, gastropods, equinoderms, polychaetes, equiurid worms, ascidians or other crustaceans (Schmitt et al., 1973; Baeza, 2015). The genus Calyptraeotheres E. Campos, 1990 is composed by six species commonly found associated to limpets of the superfamily Calyptraeoidea (Fenucci, 1975; Campos, 1990, 1999; Martins \& D’Incao, 1996; Hernández-Ávila \& Campos, 2006; Campos \& Hernandéz-Ávila, 2010; Ayón-Parente \& Hendrickx, 2016).

Calyptraeotheres garthi (Fenucci, 1975) is distributed in Brazil (state of Rio Grande do Sul) and Argentina and can be found in the mantle of calyptraeid gastropods of the genera Crepidula Lamarck, 1799, Bostrycapulus Olsson and Harbison, 1953, and Trochita Schumacher, 1817, usually associated to shells used by the hermit crab genera Petrochirus Stimpson, 1858, and Dardanus Paulson, 1875 (Hernández-Ávila \& Campos, 2006; Ayón-Parente \& Hendrickx, 2016; Boschi, 2016). Taking into consideration that the pinnotherid group is still poorly known in Brazil, especially in the states of northeast (Bezerra et al., 2006), the aim of this contribution is to provide the northernmost record of C. garthi in Atlantic Ocean, particularly in warm waters from the Northeastern Brazil.

Sampling was carried out on November 2010 at the Pacheco beach, municipality of Caucaia, state of Ceará, Brazil ( $\left.3^{\circ} 41^{\prime} 11.66^{\prime \prime} \mathrm{S} 38^{\circ} 37^{\prime} 58.78^{\prime \prime} \mathrm{W}\right)$. This area is an open beach characterized by predominance of ferruginous sandstone reefs with predominance of macro algae and a rich marine invertebrate fauna, including mainly crustaceans and mollusks (Matthews-Cascon et al., 2005). One shell of Voluta ebraea Linnaeus, 1758, occupied by the hermit crab Petrochirus diogenes (Linnaeus, 1758) was obtained by a fisherman with a otter trawl in the subtidal zone. The specimen was brought to the laboratory and examined. A specimen of the limpet Crepidula plana Say, 1822 (Figure 1A, B, C) was removed from the $V$. ebraea shell and two pea-crabs were found below Crepidula's shell (Figure 1B). The host and your symbiont crabs were photographed and posteriorly cryo-anesthetized and fixed in $70 \%$ ethanol.

The specimens of the snail and crabs were deposited respectively in the Malacological Collection Professor Henry Ramos Matthews (Série B) of the Departamento de Biologia of Universidade Federal do Ceará (CMPHRM-B 4319) and in the Carcinological Colletion of the Departamento de Zoologia, Instituto de Biociências, Universidade Federal do Rio Grande do Sul, Porto Alegre, Rio Grande do Sul, Brazil (UFRGS). Crabs were measured for the carapace width $(\mathrm{CW})$ with aid of a vernier caliper (0.01 $\mathrm{mm}$ of accuracy).

\section{SYSTEMATICS \\ Infraorder Brachyura Latreille, 1802 \\ Family Pinnotheridae De Haan, 1833 \\ Genus Calyptraeotheres E. Campos, 1990 \\ Calyptraeotheres garthi (Fenucci, 1975)}

(Figures 1-2) 
Pinnotheres politus (not Smith, 1869). - Fenucci, 1971, p. 355-367.

Pinnotheres garthi Fenucci, 1975, p. 167, 169-171, 178, figs. 1A-B, 3D, I; Campos, 1990, p. 365; Martins \& D'Incao, 1996, p. 11-13, fig. 7, 8, 14F.

Calyptraeotheres garthi. - Campos, 1999, p. 537-538, figs. 1 E-F, 2B. - Bezerra et al., 2006, p. 1043 [Appendix]. - Ayón-Parente \& Hendrickx, 2016, p. 94 [key]. - Boschi, 2016, p. 117, 118, 120, tables 1 and 2 .

Examined material: Brazil, state of Ceará, Caucaia, Praia do Pacheco $\left(3^{\circ} 41^{\prime} 11.66^{\prime \prime} \mathrm{S}\right.$ $\left.38^{\circ} 37^{\prime} 58.78^{\prime \prime} \mathrm{W}\right)$, fisherman coll., November 2010, one male (CW $1.1 \mathrm{~mm} \mathrm{~mm}$ ) and one female (CW $1.3 \mathrm{~mm}$ ) (UFRGS 6848).

Diagnosis. Martins \& D'Incao (1996).

Distribution. Southwest Atlantic: Brazil, Ceará (this contribution), Rio Grande do Sul; Argentina, Mar Del Plata, Necochea, Golfo de San Matias (Campos, 1999; Bezerra et al., 2006) (Figure 2).

Figure 1 - Calyptraeotheres garthi (Fenucci, 1975) symbiosis. A - Voluta ebraea Linnaeus, 1758, shell occupied by the hermit crab Petrochirus diogenes (Linnaeus, 1758) and with the association of the limpet Crepidula plana Say, 1822 (white arrow); B - C. plana ventral view with two symbiotic pea-crabs; $\mathrm{C}-\mathrm{C}$. plana dorsal view; D - Male of C. garthi dorsal view; E - Female of C. garthi dorsal view. Scale bars: $\mathrm{A}-\mathrm{C}=1 \mathrm{~cm} ; \mathrm{D}, \mathrm{E}=1 \mathrm{~mm}$.

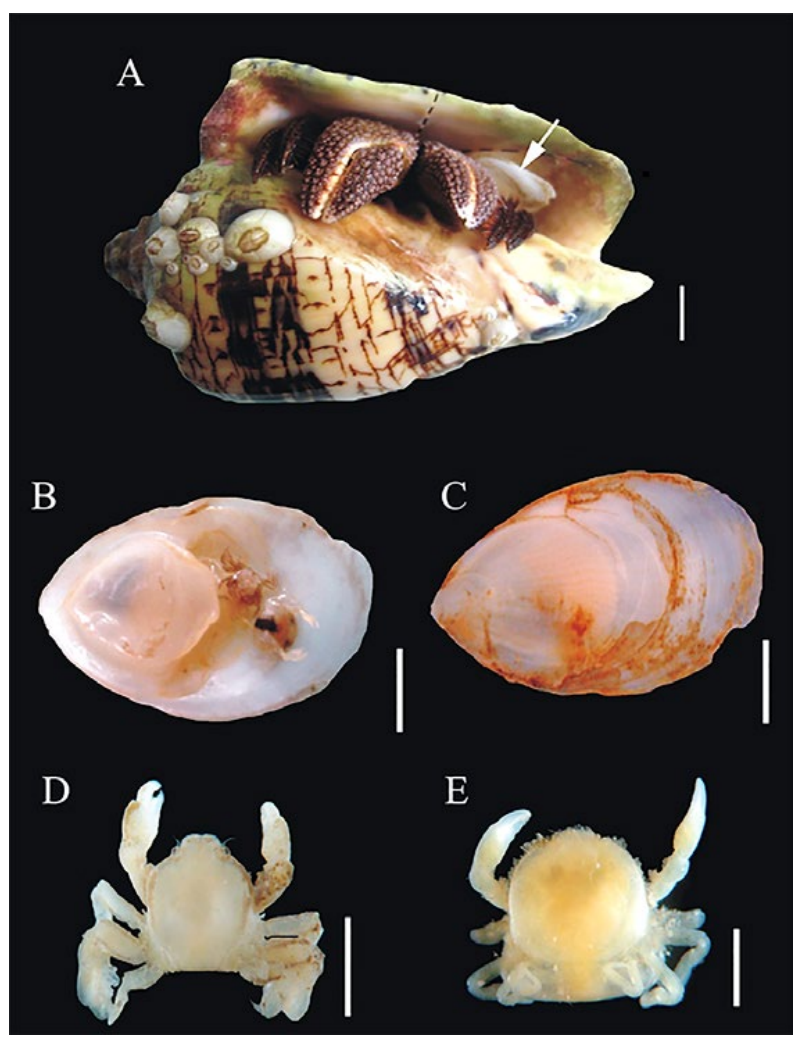


Figure 2 - Updated distribution map of Calyptraeotheres garthi (Fenucci, 1975). Black circles indicate old records and red circle indicates new record. Abbreviations: CE - Ceará; RS - Rio Grande do Sul.

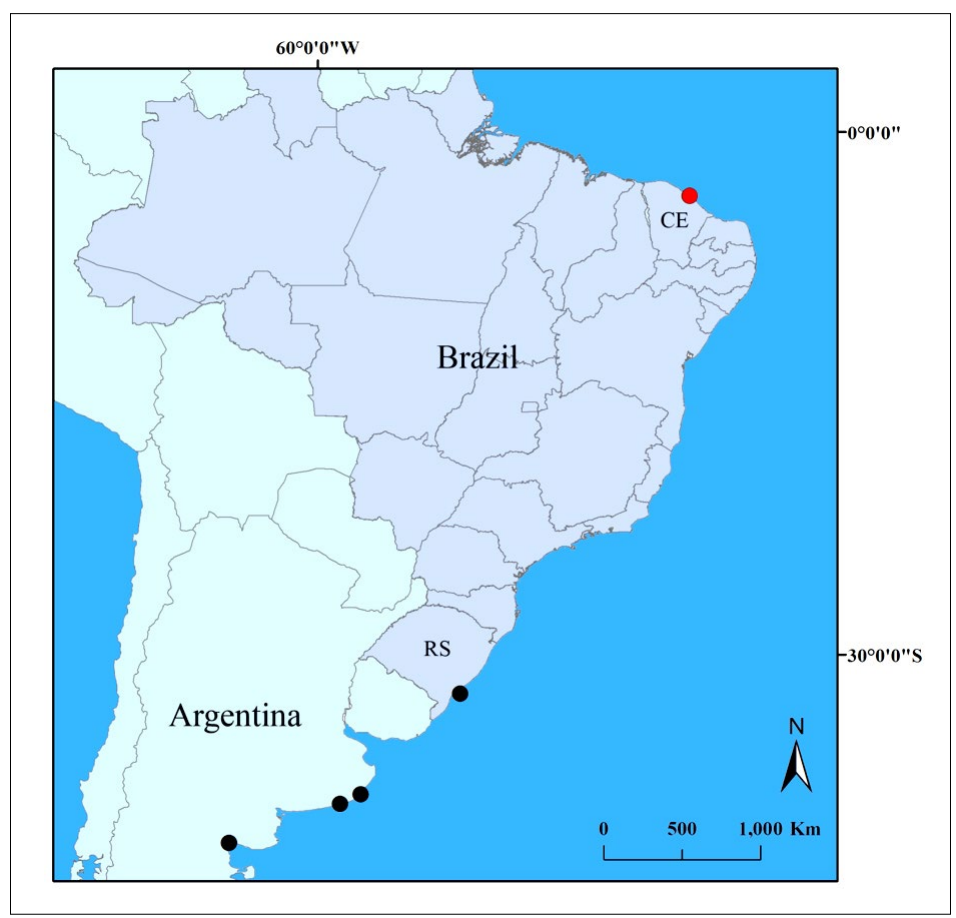

\section{ECOLOGICAL NOTES}

In Argentina, C. garthi is ubiquitous and it already recorded in almost all naturally occurring calyptraeid species, e.g. Crepidula argentina Simone, Pastorino \& Penchaszadeh, 2000, C. cachimilla Cledón, Simone \& Penchaszadeh, 2004, C. plana, Bostrycapulus odites Collin, 2005 and Trochita pileus (Lamarck, 1822) (Fenucci, 1975; Ocampo et al., 2012). In Brazil, this species was found associated with the species C. protea (d'Orbigny, 1841) in the state of Rio Grande do Sul (Martins \& D'Incao, 1996) and with C. plana in the state of Ceará (present contribution).

\section{REMARKS}

The genus Calyptraeotheres was erected to include the species Fabia granti Grassel, 1933, based on the carapace with sharp-edged anterolateral margins and the third maxilliped palp with two articles, carpus longer than propodus and pleon of seven free somites (Campos, 1990). Calyptraeotheres garthi (as Pinnotheres garthi Fenucci, 1975) was registered in Brazil for the first time by Martins \& D'Incao (1996) in the municipality of Rio Grande, state of Rio Grande do Sul.

Three years later, Campos (1999) included P. garthi and P. politus (Smith, 1869) within Calyptraeotheres and improved the genus diagnosis'. Bezerra et al., (2006) provided the first record of Pynnotheridae in the state of Ceará, listing the presence of three species, Austinixa bragantina Coelho, 2005; A. leptodactyla (Coelho, 1997) and Zaops ostreum (Say, 1817). 
However, the studies on this family are still very scarce from Brazil. This record represents the northernmost occurrence for the species in the Atlantic Ocean, being the first record of C. garthi from Northeastern Brazil and the second for Brazilian waters. This new record increases the distribution area in about $3520 \mathrm{~km}$.

The initial distribution indicated that the species was restricted to cold waters, being a species of the Argentinian Province following the biogeographic classification of Boschi (2000), where the surface temperature ranges from $8^{\circ}$ to $23^{\circ} \mathrm{C}$ in the south sector (Bueno Aires) and from $12.5^{\circ}$ to $25^{\circ} \mathrm{C}$ in the northern sector in southern Brazil (Hereu, 1999). However, the present record in tropical waters extends the distribution of the species and includes it as a species occupying also the Brazilian Province, where temperatures vary from $22^{\circ} \mathrm{C}$ in the south to $30^{\circ} \mathrm{C}$ in the north limits of the Province. According to Boschi (2000), the Argentinian Province can be characterized as a warm temperate province with 330 species, 42 of which are endemic while the in the Brazilian Province the estimated number of decapod crustacean species is 572,64 of which are endemic.

The present record of $C$. garthi in the Brazilian province extends its distribution to both provinces, as other species of Brachyura such as Apiomithrax violaceus (A. MilneEdwards, 1868), Arenaeus cribrarius (Lamarck, 1818), among others. The host species Crepidula plana also occurs in both provinces (Rios, 2002).

Acknowledgements - The authors are grateful to Coordenação de Aperfeiçoamento de Pessoal de Nível Superior and Programa de Pós-Graduação em Biologia Animal (PPGBAN/ UFRGS) for the fellowship provided to FBR (PNPD/Capes Proc. $n^{\circ} 88887.470134 / 2019-00$ ) and to Bsc. Augusto F. Huber for the helping with the distribution map.

\section{REFERENCES}

Ayón-Parente, M. \& Hendrickx, M.E. Calyptraeotheres sp. nov. (Crustacea: Decapoda: Pinnotheridae), symbiont of the slipper shell Crepidula striolata Menke, 1851 (Mollusca: Gastropoda: Calyptraeidae) from the Gulf of California, Mexico. Zootaxa, v. 3872, n. 1, p. 089-094, 2014. http://dx.doi.org/10.11646/zootaxa.3872.1.8

Baeza, J.A. Crustaceans as symbionts: an overview of their diversity, host use and life styles, p. 163-189, in Watling, L. \& Thiel, M. (eds.). The Life Styles and Feeding Biology of the Crustacea, 584 p., Oxford University Press, 2015.

Bezerra, L.E.A.; Almeida, A.O. \& Coelho, P.A. Occurrence of the family Pinnotheridae De Haan (Crustacea, Decapoda, Brachyura) on the coast of Ceará State, Brazil. Rev. Bras. Zool., v. 23, n. 4, p. 1038-1043, 2006. https://doi.org/10.1590/S0101-81752006000400008

Boschi, E.E. Species of decapod crustaceans and their distribution in the American marine zoogeographic provinces. Rev. Inv. Des. Pesq., p. 7-136, 2000.

Boschi, E.E. Los crustáceos de interés pesquero y otras especies relevantes em los ecosistemas marinos. Mar del Plata: Instituto Nacional de Investigación y Desarrollo Pesquero INIDEP, 271 p., 2016.

Campos, E. Calyptraeotheres, a new genus of Pinnotheridae for the limpet crab Fabia granti Glassell, 1933 (Crustacea, Brachyura). Proc. Biol. Soc. Wash., v. 103, p. 364-371,1990. 
Campos, E. Inclusion of the austral species Pinnotheres politus (Smith, 1869) and Pinnotheres garthi Fenucci, 1975 within the genus Calyptraeotheres Campos, 1990 (Crustacea: Brachyura: Pinnotheridae). Proc. Biol. Soc. Wash., v. 112, p. 536-540, 1999.

Campos, E. \& Hernández-Ávila, I. Phylogeny of Calyptraeotheres Campos, 1990 (Crustacea, Decapoda, Brachyura, Pinnotheridae) with the description of $C$. pepeluisi new species from the tropical Mexican Pacific. Zootaxa, v. 2691, n. 1, p. 41-52, 2010. http://dx.doi.org/10.11646/ zootaxa.2691.1.2

Fenucci, J.L. Notas sobre las dos especies de pinoteridos mas comunes del litoral bonaerense (Decapoda, Brachyura, Pinnotheridae). Physis, serie A, v. 30, n. 81, p. 355-367, 1971.

Fenucci, J.L. Los cangrejos de la familia Pinnotheridae del litoral argentino (Crustacea, Decapoda, Brachyura). Physis, seccion A, v. 34, n. 88, p. 165-184, 1975.

Hereu, C.M. Aspectos biológicos e ecológicos durante o período pelagial de Libinia spinosa (Milne Edwards, 1834) (Brachyura: Majidae) no litoral do Rio Grande do Sul, Brasil. Dissertação de mestrado, Fundação Universidade do Rio Grande, 135 p., Rio Grande, 1999.

Hernández-Ávila, I. \& Campos, E. Calyptraeotheres hernandezi (Crustacea: Brachyura: Pinnotheridae), a new crab symbiont of the West Indian cup-and-saucer Crucibulum auricula (Gmelin) (Mollusca: Gastropoda: Calyptraeidae) off Cubagua Island, Venezuela. Proceedings of the Biological Society of Washington, v. 119, n. 1, p. 43-48, 2006. https://doi. org/10.2988/0006-324X(2006)119[43:CHCBPA]2.0.CO;2

Martins, S.T.S. \& D’Incao, F. Os Pinnotheridae de Santa Catarina e Rio Grande do Sul, Brasil (Decapoda, Brachyura). Rev. Bras. Zool., Curitiba, v. 13, n. 1, p. 1-26, 1996.

Matthews-Cascon, H.; Franklin Jr., W.; Bezerra, L.E.A.; Meirelles, C.A.O. \& Soares, M.O. Levantamento da macrofauna bentônica de ambientes consolidados (região entremarés de praias rochosas), In Instituto de Ciências do Mar (Labomar/UFC). Zoneamento ecológico econômico (ZEE) da Zona Costeira do Estado do Ceará, 124 p., 2005.

Ocampo, E.H.; Nuñez, J.D.; Cledón, M. \& Baeza, J.A. Host-specific reproductive benefits, host selection behavior and host use pattern of the pinnotherid crab Calyptraeotheres garthi. J. Exp. Mar. Biol. Ecol., v. 429, p. 36-46, 2012. https://doi.org/10.1016/j.jembe.2012.06.009

Schmitt, W.L.; McCain, J.C. \& Davidson, E.S. Decapoda I. Brachyura I. Family Pinnotheridae, p. 1-160, in Gruner, H.-E. \& Holthuis, L.B. (eds.). Crustaceorum catalogus, v. 3., 1973. 